\title{
PENGARUH PENAMBAHAN BAKTERI (Lactobacillus sp.) DENGAN KONSENTRASI BERBEDA TERHADAP PERTUMBUHAN UDANG VANNAMEI (LitopenaeusVannamei)
}

\author{
THE EFFECT OF THE ADDITION OF BACTERIA (Lactobacillus Sp.) WITH \\ DIFFERENT CONCENTRATION TOWARDS VANNAMEI SHRIMP GROWTH \\ (Litopenaeus vannamei)
}

\author{
Ali Syadillah ${ }^{1 *)}$, Siti Hilyana ${ }^{2)}$, Muhammad Marzuki ${ }^{1)}$ \\ ${ }^{1)}$ Program Studi Budidaya Perairan, Universitas Mataram \\ ${ }^{2)}$ Program Studi Ilmu Kelautan, Universitas Mataram \\ *)alamat korespondensi: syadillahali75@gail.com
}

\begin{abstract}
Abstrak
Tujuan dilakukan penelitian ini adalah untuk mengetahui pengaruh penambahan Lactobacillus sp., terhadap pertumbuhan berat, panjang, SR (Survival Rate) dan FCR (Feed Convertion Ratio) udang vaname (Litopenaeus vanamei). Penelitian ini dilakukan menggunakan 4 (empat) perlakuan dan 3 (tiga) ulangan dengan perlakuan $\mathrm{P}_{1}=(7 \%), \mathrm{P}_{2}=(9 \%)$, $\mathrm{P}_{3}=(11 \%)$ dan $\mathrm{P}_{4}=(13 \%)$. Lokasi penelitian di Desa Kidang dan Laboratorium Mikrobiologi Fakultas Pertanian, pada tanggal 30 April-13 Mei tahun 2019. Pemeliharaan udang selama 45 hari kemudian diukur parameter atau pengaruh perlakuan hasil penelitian menunjukkan bahwa penambahan bacteri Lactobacillus sp. sebagai berikut : pertumbuhan berat terendah yaitu pada $\mathrm{P}_{1}=6,3667 \pm 0,17 \mathrm{~g} /$ ekor sedangkan tertinggi pada $\mathrm{P}_{4}=7,6 \pm 0,23 \mathrm{~g} / \mathrm{ekor}$, pertumbuhan panjang terendah yaitu pada $\mathrm{P}_{1}=4,4067 \pm 0,41 \mathrm{~cm} /$ ekor sedangkan $\mathrm{P}_{4}=5,4067 \pm 0,12 \mathrm{~cm} / \mathrm{ekor}, \mathrm{SR}$ (SurvivalRate) terendah terdapat pada $\mathrm{P}_{1}=76,6 \%$ sedangkan tertinggi pada $\mathrm{P}_{3}=83,0 \%$ dan FCR (Feed Comvertion Rate) terendah terdapat pada $\mathrm{P}_{3}=2,6067 \pm 0,15$ sedangkan tertinggi terdapat pada $\mathrm{P}_{1}=2,6067 \pm 0,15$.
\end{abstract}

Kata kunci: Laktobacillus sp., konsentrasi, pertumbuhan

\begin{abstract}
Vaname shrimp has several advantages compared to tiger shrimp that is they are more resistant to disease. Vaname shrimp can be maintained with a very wide salinity range, that is between 0.5-45 ppt.One of the deep problems in vaname shrimp cultivation is the growth of Vaname shrimp which is very slow due to inappropriate management of feed.The purpose of the study is to know the effect of the addition of Lactobacillus sp to the growth of weight, length, SR and FCR Vaname shrimp (Litopanaeus vanamei). This study was conducted using 4 (four) treatments and 3 (three) replications with treatment $\mathrm{P} 1=(7 \%), \mathrm{P} 2=(9 \%), \mathrm{P} 3=(11 \%)$ and $\mathrm{P} 4=(13 \%)$ research location was in Kidang Village and Microbiology Laboratory, Faculty of Agriculture, on April 30-May 13 2019. Plant for 45 days and by measuring the parameters or treatment effects. The results showed that the addition of Lactobacillus sp. as follows, the lowest weight growth is at $\mathrm{P} 1=\mathrm{P}_{1}=6,3667 \pm 0,17 \mathrm{~g} /$ head while the highest is in $\mathrm{P}_{4}=7,6 \pm 0,23 \mathrm{~g}$ / head,the lowest weight growth is at $\mathrm{P}_{1}=4,4067 \pm 0,41$ while $\mathrm{P}_{4}=5,4067 \pm 0,12$, the lowest SR is at $\mathrm{P} 1=76.6 \%$ while the highest at $\mathrm{P} 3=83.0 \%$ and the lowest FCR is at $\mathrm{P}_{3}=2,6067 \pm 0,15$ while the highest is at $\mathrm{P}_{3}=2,6067 \pm 0,15$.
\end{abstract}


Keywords: Laktobacillus sp., Concentration, growth

\section{PENDAHULUAN}

Udang vaname

(Litopenaeus vannamei) adalah spesies udang yang bernilai ekonomis tinggi dan merupakan salah satu komoditas unggulan nasional. Beberapa tahun terakhir hasil budidaya udang vaname terus mengalami peningkatan. Hal ini tergambar dari jumlah ekspor udang vaname yang terus mengalami peningkatan. Pada tahun 2012 jumlah ekspor udang vaname sebanyak112.066 ton BPS RI (2012). Pada lima tahun terakhir volume ekspor udang Indonesia mengalami turun naik, peningkatan paling signifikan terjadi pada tahun 2014 yaitu 1.875 juta ton dan pada tahun 2017 sejumlah 1.746 juta ton yang mulanya pada tahun 2012 sebanyak 1.152 juta ton. Untuk skala jumlah ekspor udang menepati posisi terendah, namun untuk skala nilai menepati posis tertinggi 4 tahun terakhir. Dimana pada tahun 2014 (KKP, 2018). Sedangkan provinsi NTB pada tahun 2016 menyumbang 56.960,19 ton produksi udang nasional. Produksi udang vaname ini akan terus mengalami peningkat.

Potensi areal budidaya air payau termasuk di dalamnya udang vaname di NTB, seluas 26.287,5 ha dengan tingkat pemanfaatan seluas $5.529,0$ ha $(21,03 \%$ dari potensi). BPS NTB (2013). Hal ini menunjukan bahwa potensi untuk mengembangkan budidaya udag vaname masih terbuka lebar dari segi lahan. Pemanfaatan lahan secara optimal dengan teknologi yang dapat membuat pertumbuhan udang menjadi optimal dan ramah lingkungan diyakini akan membuat hasil produksi terus meningkat dan kegiatan budidaya akan berkelanjutan.

Salah satu permasalahan dalam dalam budidaya udang vaname yaitu pertumbuhan udang vaname yang lambat akibat pengelolaan pakan yang tidak sesuai Nuhman (2008). Penambahan bakteri gram positif pada pakan secara ilmiah diyakini dapat meningkatkan pertumbuhan udang vaname. Di antara bakteri gram positif yang biasa ditambahkan pada kegiatan budidaya udang vanamei yaitu bakteri Lactobacillus sp., bakteri ini memiliki banyak keuntungan bagi kelangsungan hidup udang vaname pada kegiatan budidaya (Andriani et al., 2017).

Lactobasillus sp adalah bakteri gram positif dan jika dicampurkan pada pakan udang vaname dalam kosenterasi tertentu dapa meningkatkan pertumbuhan udang vaname. Lactobacillus sp., akan menyehatkan usus dan dapat menyederhanakan senyawa-senyawa protein sehingga dalam proses penyerapan makanan menjadi lebih optimal sehingga pakan yang diberikan terfokus pada petumbuhan Andriani at al, (2017). Selain itu Lactobacillus sp., dapat menekan bakteri-bakteri penyebab penyakit yang dapat membuat pertumbuhan udang vaname menjadi lambat akibat energi yang dihasilkan dari pankan terfokus untuk daya tahan tubuh udang vaname, akibatnya pertumbuhan udang vaname jadi meningkat (Ferdyanan et al., 2017).

Atas dasar tersebut maka penelitian ini akan dilakukan untuk mengetahui pengaruh perbedaan kosentrasi Lactobacillussp., terhadap pertumbuhan udang vannamei (Litopenaeus vannamei).

\section{METODE PENELITIAN Waktu dan tempat}

Penelitian dilakukan di lahan mandiri di Desa Kidang, Kecamatan Praya Timur, Kabupaten Lombok Tengah, Provinsi NTB, berlangsung selama 45 hari, mulai dari tanggal 29 Maret- 11 Mei 2019.

\footnotetext{
Alat dan Bahan

Beberapa alat dan bahan yang digunakan. Bahan yang digunakan adalah sebagai berikutBak plastik $(60 \times 30 \times 35) \mathrm{cm}$, Pompa akuarium, DO meter, $\quad \mathrm{pH}$ meter,Refraktometer, Seserhalus, Neraca/timbangan, Waring, Termometer, Pipa akuarium, Laminar, Cawan petri, Bunsen, Tabung reaksi, Rak tabung reaksi,
} 
Autoklaf, Aluminium foil, Kapas, Pipet mikro, Gelas ukur, Gelas abu dan Korek api, sedangkan bahan yang digunakan sebagai berikut Udang Vannamei, Air payau (15-25) ppt, Bakteri Lactobacillus sp., Tetes tebu, Ragi, Akuades, 0,5\% tripton, $0,25 \%$ ekstrak ragi, $0,1 \%$ glukosa dan $1,5 \%$ agar

\section{Racangan Penelitia}

Penelitian ini dilakukan dengan metode eksperimental menggunakan Rancangan Acak Lengkap (RAL). Pemilihan Acak lengkap digunakan karena perlakuan homogen dan hanya menggunakan satu faktor uji saja. Aspek yang diteliti adalah perbedaan pertumbuhan mutlak dan pertumbuhan spesifik udang vanamei (Litopanaeus vannamei)dengan menggunakan penambahan bakteri Lactobacillus sp., pada persentase berbeda yaitu $\left(\mathrm{P}_{1}=7 \%, \mathrm{P}_{2}=9 \%, \mathrm{P} 3=11 \%\right.$ dan $\mathrm{P}_{4}=$ $13 \%$. Penelitian ini dilakukan dengan empat percobaan dan tiga kali pengulangan. Penempatan tata letak ulangan dari percobaan penelitian ditentukan menggunakan sistem lotre

\section{Pertumbuhan Mutlak}

Pertumbuhan mutlak dapat dihitung menggunakan rumus Effendi (1979) dalam Pratama et al., (2017) yaitu, W = Wt - Wo. Dimana, $\mathrm{W}=$ Pertumbuhan bobot individu utlak hewan uji $(\mathrm{g}), \mathrm{W}_{\mathrm{t}}=$ Bobot udang pada akhir penelitian (g) dan $\mathrm{Wo}=$ Bobot udang pada awal penelitian (g).

\section{Pertumbuhan panjang Mutlak}

Pertumbuhan panjang mutlak dapat dihitung menggunakan rumus Effendi (1979) dalam Pratama et al., (2017) yaitu, $\mathrm{L}=\mathrm{L}_{\mathrm{t}}-\mathrm{L}_{0}$. Dimana, $\mathrm{L}=$ Pertumbuhan panjang mutlak udang $(\mathrm{cm}), \mathrm{L}_{\mathrm{t}}=$ Panjang udang pada akhir penelitian $(\mathrm{cm})$, dan $\mathrm{L}_{0}=$ Panjang udang pada awal penelitian (cm).

\section{SR (Survival Rate)}

SR (Survival Rate) atau tingkat kelangsungan hidup dapat dihitung menggunakan rumus Paratama et al., (2017) yaitu, $S R=\left(\mathrm{N}_{\mathrm{t}} / \mathrm{N}_{0}\right) \times 100 \%$. Dimana, $\mathrm{SR}=$ Kelangsungan hidup $(\%), \mathrm{N}_{\mathrm{t}}$ $=$ Jumlah udang akhir (ekor), dan $\mathrm{N}_{0}=$ Jumlah udang awal (ekor).

\section{FCR (Feed Conversion Ratio)}

FCR (Feed Conversion Ratio) dapat dihitung menggunakan rumus Paratama et al., (2017) yaitu, FCR = F/biomassa $\mathrm{x}$ 100\%. Dimana, FCR $=$ Feed Conversion Ratio (Rasio Konversi Pakan), F = Jumlah pakan yang diberikan selama penelitian $(\mathrm{kg})$, dan Biomassa = Biomassa udang diakhir penelitian $(\mathrm{kg})$.

\section{Parameter Kualitas air.}

Air merupakan media tempat hidup udang sehingga kualitasnya harus tetap terjaga sehingga terus dilakukan monitoring. Parameter kualitas air yang diamati yaitu meliputi DO (Dissovd Oxygen), $\mathrm{pH}$ (Power of Hidrogen)dan salinitas (Tehe et al., 2011).

\section{Analisis Data}

Parameter yang diuji secara statistik adala pertumbuhan berat mutlak, panjang mutlak, SR (Survival Rate) dan FCR (Feed Comvertion Ratio) selama 45 hari menggunakan aplikasi SPSS dengang tingkat eror sebesar 0,5 .

\section{HASIL DAN PEMBAHASAN Pertumbuhan Mutlak}

Data rata-rata berat udang vaname setelah pemberian pakan dengan penambahan probiotik (Lactobacillus sp.) pada persentase pakan berbeda selama 45 hari pemeliharaan disajikan pada Gambar1. 


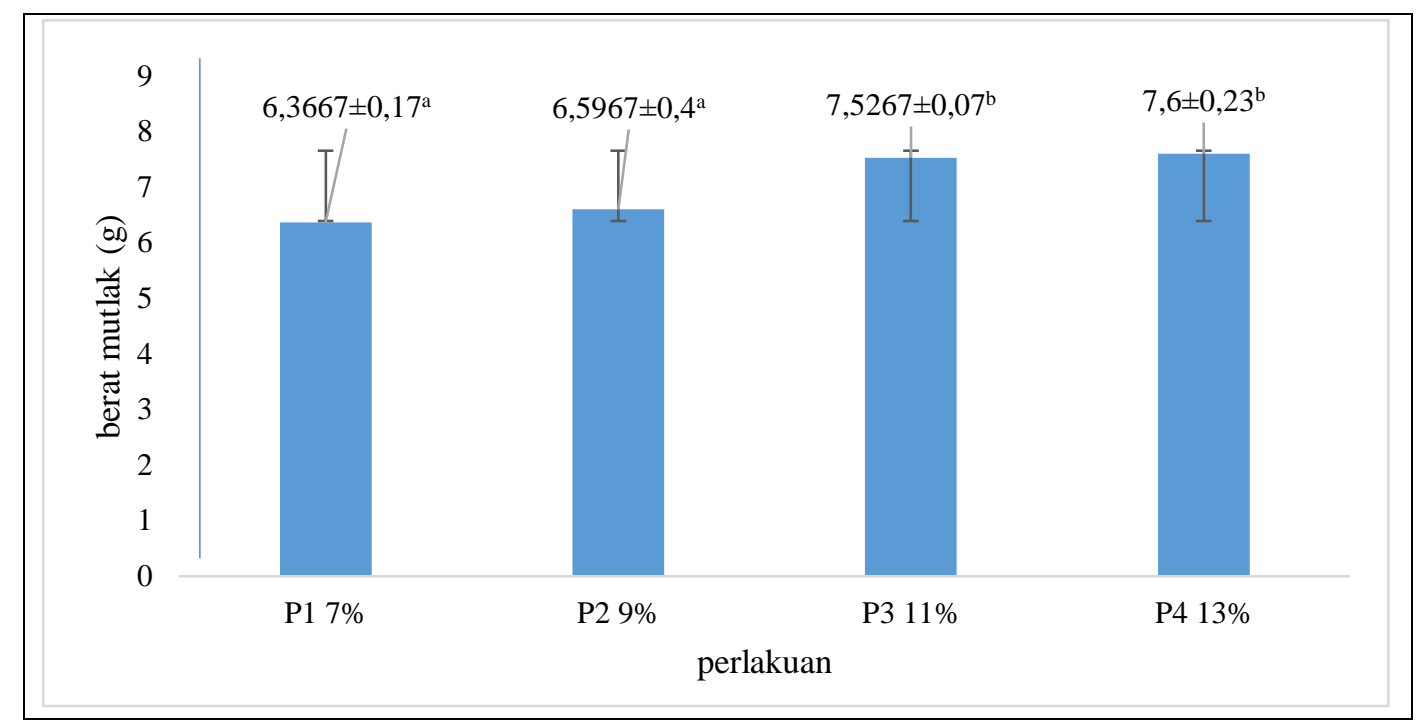

Gambar 1. Grafik berat udang vaname setelah pemberian probiotik dengan persentase pakan berbeda selama 45 hari.

Pertumbuhan merupakan suatu peroses yang terjadi pada setiap makhluk hidup dan merupakan ciri-ciri dari makhluk hidup itu sendiri. Pertumbuhan merupakan suatu peroses terjadinya pertambahan bobot dan panjang tubuh yang bersifat ireversibel (tidak dapat kembali ke keadaan semula). Pertambahan bobot dan panjang tubuh ini terjadi diakibatkan oleh suatu proses pembengkakan dan atau pembelahan sel pada jaringan tubuh. Pertumbuhan dapat diketahui dengan melihat perubahan atau membandingkan bobot atau panjang tubuh makhluk hidup yang bersangkutan. Pada kegiatan penelitian ini pertumbuhan udang vaname yang diamati yaitu pertumbuhan berat dan panjang (Suwoyo dan Mangampa, 2010).

Hasil penelitian berat udang vaname selama 45 hari dilihat dari Gambar 1. memperlihatkan hasil pertumbuhan dari yang terendah sampai yang tertinggi yaitu P1 dengan pertambahan berat 6,3667 $\pm 0,17 \mathrm{~g} / \mathrm{ekor}, \quad \mathrm{P} 2$ dengan pertambahan berat $6,5967 \pm 0,4 \mathrm{~g}$ /ekor, P3 dengan pertambahan berat $7,5267 \pm 0,07 \mathrm{~g} /$ ekor dan $\mathrm{P} 4$ dengan pertambahan berat $7,6 \pm 0,23 \mathrm{~g} /$ ekor. $\mathrm{P} 4$ dengan pertambahan berat $7,6 \pm 0,23 \mathrm{~g} / \mathrm{ekor}$ cenderung lebih tinggi dibandingkan yang lainnya. Perbedaan pertumbuhan berat udang vaname ini diduga karena adanya penambahan bakteri Lactobacillus sp. pada pakan yang mana Lactobacillus sp. ini mengandung enzim protease yang mana dapat menyederhanakan protein kompleks menjadi protein yang lebih sederhana sehingga mudah diserap oleh usus udang. Purnamasari (2017) menyatakan bahwa penambahan Lactobacillus sp. dapat mengingkatkan nafsu makan udang vaname dikarenakan adanya bau atraktan. Penambahan bakteri probiotik dapat mengurangi sebagian proses enzimatik dalam tubuh sehingga energi tersebut dialih fungsikan kedalam proses pertumbuhan sehingga pertumbuhan udang vaname menjadi lebih cepat. Menurut Novita (2016), penambahan bakteri Latobacillus sp. dapat memecahkan senyawa protein kompeks menjadi lebih sederhana, seperti menjadi oligopeptida pendekatau asam amino melalui reaksi hidrolisis pada ikatan peptida oleh enzim protease sehingga mudah diserap tubuh. Pertambahan Lactibacillus sp. juga dapat meningkatkan nafsu makan udang akibat produksi atraktan melalui peroses fermentasi anaerob. Yuliner et al., (2006) menyatakan bahwa ketika bakteri Lactobacilus sp. menjalankan peranannya sebagai probiotik maka pengeluaran enzim tertentu pada tubuh udang dalam memecahkan senyawasenyawa kimia makanan semakin 
berkurang sehingga udang dapat menghemat energi metabolisme dan penghematan energi tersebut digunakan untuk pertumbuhan udang, sehingga udang tumbuh dengan baik.

Hasil uji anova menunjukan bahwa penambahan Lactobacillus sp. pada pakan memberikan pengaruh yang signifikan $(\mathrm{p}<0,05)$ terhadap pertambahan bobot tubuh udang, sehingga perlu dilakukan uji lanjut menggunakan Tukey untuk mengetahui perlakuan yang terbaik diantara ke-4 perlakuan tersebut. P4 merupakan memiliki pertumbuhan yang tertinggi dan signifikan dengan P1 dan P2, tetapi tidak signifikan dengan P3. Perlakuan terbaik terdapat pada P3 dan P4, hal ini diduga karena semakin tinggi persentase penambahn Lactobacillus sp. pada pakan makan akan semakin meningkatkan kecernaan menjadi lebih tinggi sehingga pertumbuhan udang akan semakin lebih cepat. Hal tersebut diduga karena semakin tinggi dosis probiotik yang ditambahkan pada pakan, maka semakin tinggi pula tingkat kecernaan pakan yang disebabkan adanya aktivitas bakteri probiotik Lactobacillus casei. Menurut Arsyad et al. (2015). bahwa pertumbuhan udang vaname yang baik memiliki pertambahan berat antara 1-1,25 g/minggu atau rata-rata mencapai 7,2179 gr selama 45 hari. Nadhif (2016) juga menyatakan dalam hasil penelitiannya bahwa pada hasil perlakuan terbaiknnya $\mathrm{P}_{3}$ dengan penambahan probiotik Lactobacillus sp. menggunakan konsetrasi $15 \mathrm{ml} / \mathrm{kg}$ pakan mendapatkan pertambahan berat mutlak udang senilai 7,184 gr. Pada penelitian Nadif (2016), pemberian pakan dilakukan sebanyak 3 kali sehari sedangkan pemberian pakan pada penelitian ini dilakukan 4 kali dalam sehari.

\section{Pertumbuhan Harian Relatif}

Data rata-rata pertumbuhan berat harian relatif udang vaname setelah pemberian pakan dengan penambahan probiotik (Lactobacillus sp.) pada persentase pakan berbeda selama 45 hari pemelihatraan disajikan pada Gambar 2.

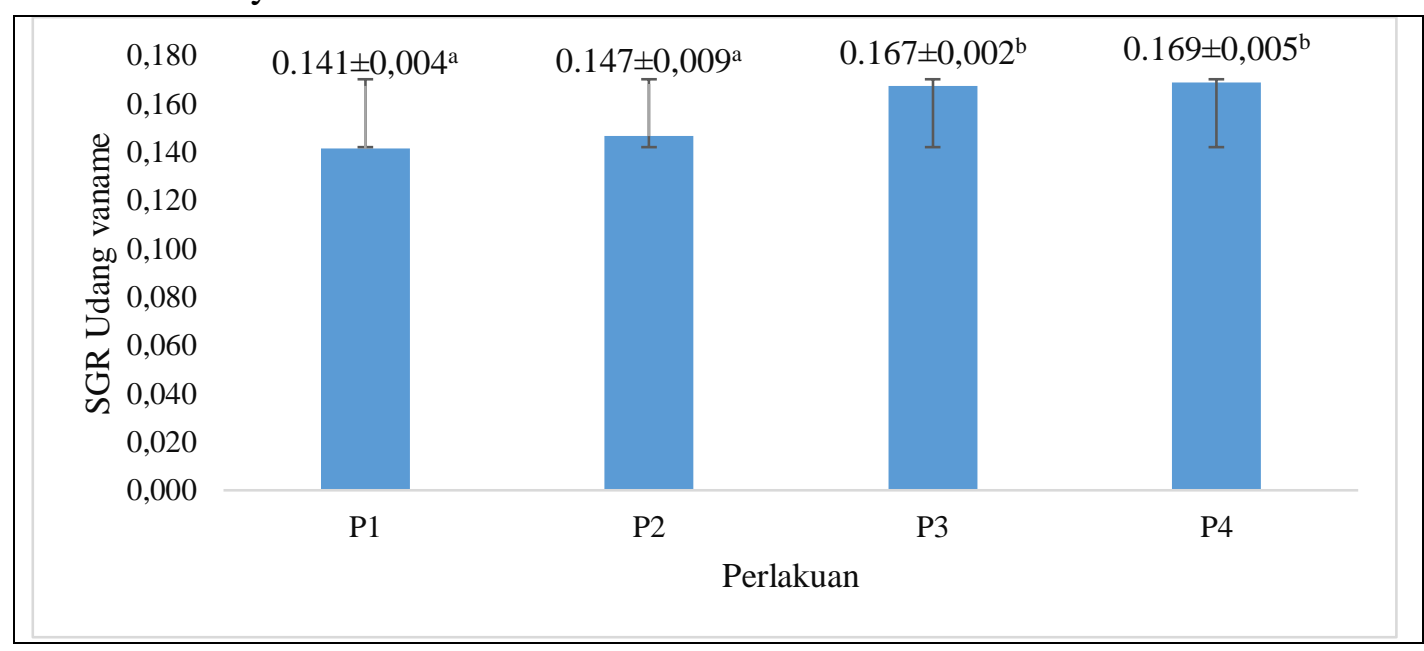

Gambar 2. Grafik pertumbuhan berat harian relatif udang vanme setelah pemberian probiotik dengan persentase pakan berbeda selama 45 hari.

Hasil SGR terendah sampai yang tertinggi pada setiap perlakuan yaitu $\mathrm{P} 1$ dengan pertambahan berat $0.141 \pm 0,004 \mathrm{~g}$ /ekor, $\mathrm{P} 2$ dengan pertambahan berat $0.147 \pm 0,009 \mathrm{~g} /$ ekor, $\mathrm{P} 3$ dengan pertambahan berat $0.167 \pm 0,002 \mathrm{~g} / \mathrm{ekor}$ dan P4 dengan pertambahan berat
$0.169 \pm 0,005 \mathrm{~g} / \mathrm{ekor}$. perlakuan $\mathrm{P} 4$ dengan pertambahan berat $0.169 \pm 0,005 \mathrm{~g} /$ ekor merupakan SGR tertinggi dari ke empat perlakuan. Hal ini sebabkan oleh penambahan bakteri Lactobacillus sp. dengan persentase pakan berbeda, memperlihatkan semakin tingginya 
pemberian Laktobacillus sp. menyebabkan semakin tinggi pertumbuhan berat relatif akibat aktivitas enzimatik bakteri Lactobacillus sp. yang membuat penyerapan pakan menjadi lebih optimal pada usus. Yuliner et al., (2006) menyatakan bahwa probiotik Lactobacillus sp. akan memecahkan senyawa-senyawa kimia seperti seperti protein menjadi lebih sederhana sehingga mudah diserap usus untuk pertumbuhan.

\section{Pertumbuhan Panjang Mutlak}

Data rata-rata panjang udang vaname setelah pemberian pakan dengan penambahan probiotik Lactobacillus sp. dengan persentase pakan berbeda selama 45 hari pemelihatraan disajikan pada Gambar 3.

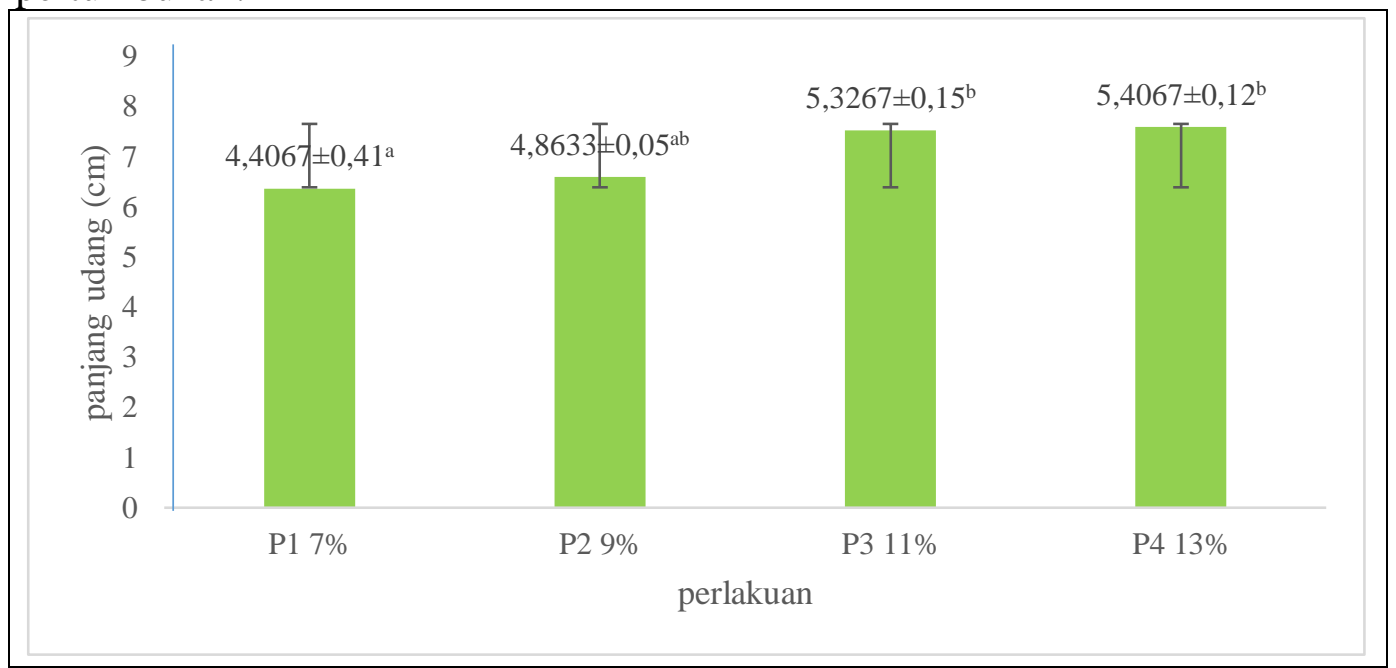

Gambar 3. Panjang udang vanme setelah pemberian probiotik dengan persentase pakan berbeda selama 45 hari.

Hasil penelitian panjang udang vaname selama 45 hari memprlihatkan hasil pertumbuhan panjang mutlak dari yang terendah sampai yang tertinggi yaitu P1

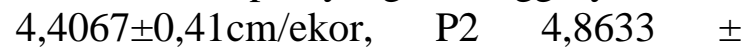
$0,05 \mathrm{~cm} /$ ekor, $\mathrm{P} 35,3267 \pm 0,15 \mathrm{~cm} /$ ekor dan P4 5,4067 $\pm 0,12 \mathrm{~cm} /$ ekor. P4 dengan pertambahan panjang 5,4067 \pm $0,12 \mathrm{~cm} /$ ekor cendrung lebih tinggi dibandingkan yang lainnya. Perbedaan pertumbuhan udang vaname ini diduga karena adanya penambahan bakteri Lactobacillus sp. pertambahan panjang yang terjadi diyakini akibat penambahan bakteri Lactobacillus sp. yang diberikan mengandung Lactobacillus plantarum yang memiliki kemampuan untuk mempercepat penyerapan protein sehingga udang memiliki pertambahan panjang yang baik. Pemberian Lactobacillus palantarum yang masuk ke saluran pencernaan akan berkembangbiak dan membatu proses penyerapan protein untuk pertumbuhan panjang dan berat, Arsyad et al., (2017). Menurut Fernando (2016) bahwa udang vaname yang diberikan probiotik cendrung memberikan pertumbuhan yang lebih tinggi jika dibandingkan dengan udang vaname yang tidak diberikan penambahan bakteri probiotik.

Hasil uji anova menunjukan bahwa pemberian probiotik pada pakan memberikan pengaruh yang signifikan $(p<0,05)$ terhadap pertambahan panjang udang. Maka untuk mendapatkan perlakuan terbaik dilakukan uji lanjut menggunakan uji Tukey sehingga didapatkan hasil tertinggi pada perlakuan P4 dan signifikan dengan perlakuan P1, tetapi tidak signifikan dengan P2 dan P4. Hal ini menunjukan adanya pengaruh penambahan probiotik dengan konsentrasi berbeda terhadap laju pertumbuhan panjang udang vaname karena penambahan Lactobacillus sp. dapat 
menambah nafsu makan udang sehingga pakan yang dikosumsi menjadi lebih tinggi yang dapat meningkatkan pertumbuhan panjang udang. Effendi (1979) menyatakan bahwa pertumbuhan udang dapat dipengaruhi oleh genetis, jenis kelamin, umur, penyakit serta kemampuanya mencerna makanan. Konsumsi pakan sangat mempengaruhi pertumbuhan, karena

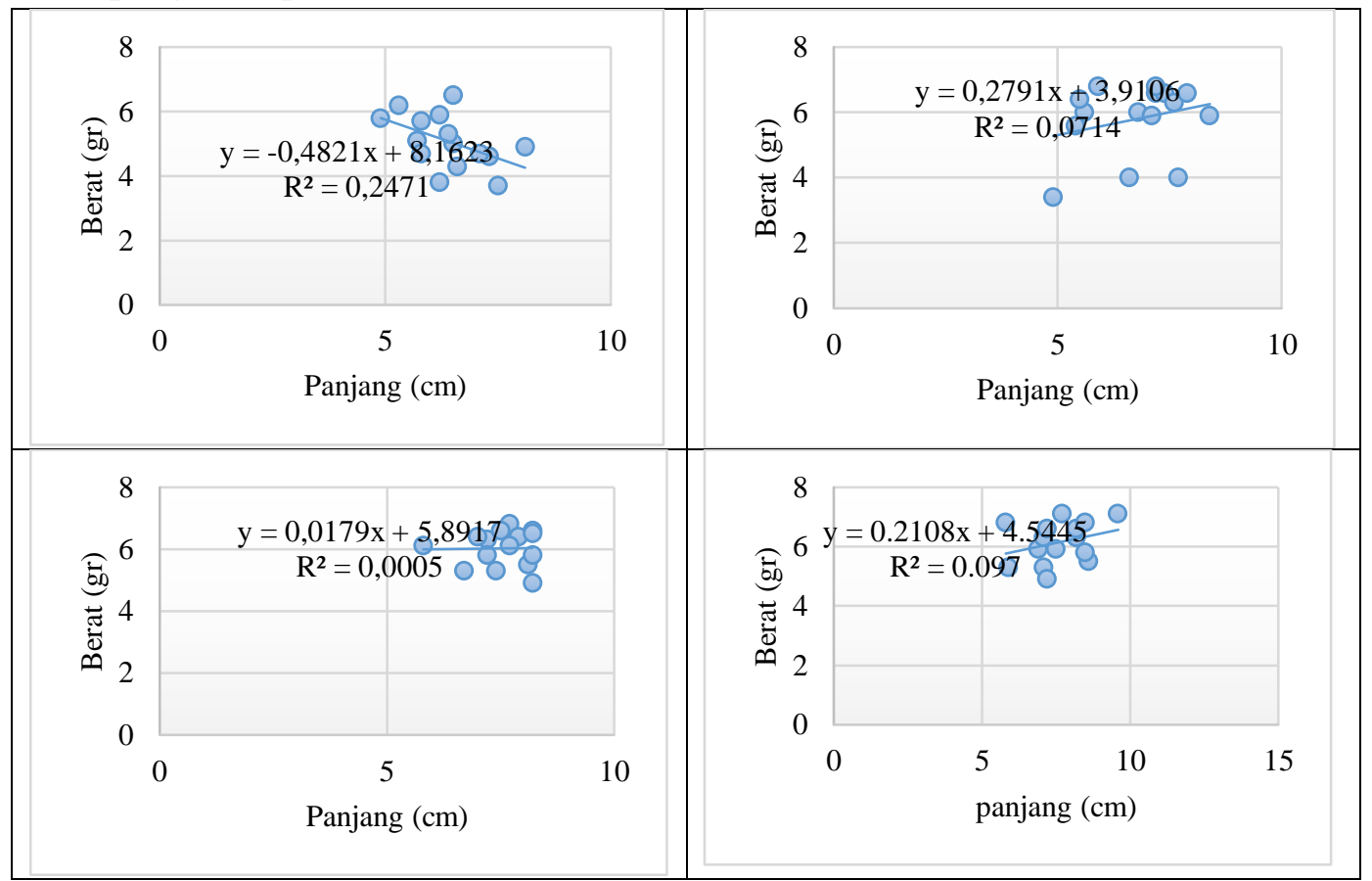

Gambar 4. Hubungan panjang dan berat udang vaname.

Berdasarkan Gambar 4. di atas udang vaname rata-rata memiliki pertumbuhan berat yang yang berbanding lurus dengan pertumbuhan panjang tubuh udang vaname. Setelah dilakukan analisis hubungan panjang dan berat udang vaneme berurutan dari perlakuan P1 sampai dengan $\mathrm{P} 4$ secara berurutan yaitu $\mathrm{P} 1 \mathrm{y}=0,4821 \mathrm{x}+$ $8,1623, P 2 \mathrm{y}=0,2791 \mathrm{x}+39106, \mathrm{P} 3 \mathrm{y}=$ $0,0179 \mathrm{x}+5,8917$ dan $\mathrm{P} 4 \mathrm{y}=0,2108 \mathrm{x}+$ 4.5445. Hasil tersebut memperlihatkan bahwa pertumbuhan berat udang vaname lebih dominan dibandingkan pertumbuhan panjang $(b>3)$ atau biasa disebut pola allometrik positif. Pertumbuhan ini tidak seperti pola hubungan panjang dan berat udang pada umumnya $(b<3)$, karena udang yang digunakan pada kegiatan penelitian ini memiliki ukuran yang sudah besar. Udang vaname yang sudah besar pada kondisi pakan yang dikonsumsi akan dicerna untuk pertumbuhan dan berbagai keperluan tubuh lainnya.

\section{Hubungan Panjang dan Berat}

Hubungan Panjang berat dapat dilihat pada gambar 4 .

normal, pertumbuhannya akan lebih tertuju pada penggemukan sehingga pertumbuhan panjangnya akan melambat bahkan bisa terhenti. Ini sesuai dengan pernyatan Rohmi dan Desrita (2018), udang yang mendekati dewasa pertumbuhan beratnya akan lebih cepat dari pertumbuhan panjangnya. Penambahan bakteri Lactobacillus sp. dengan persentase berbeda akan menambah nafsu makan udang sehingga pertumbuhan beratnya akan semakin meningkat. Nadhif (2017), pada penelitiannya menyatakan bahwa nafsu makan dan retensi pakan akan semakin tinggi sehingga pertumbuhan udang akan semakin baik.

\section{Survival Rate (SR)}

Data rata-rata Survival Rate (SR) udang vaname setelah pemberian pakan dengan penambahan probiotik 
Lactobacillus sp. dengan persentase pakan berbeda selama 45 hari pemelihatraan disajikan pada Gambar 5.

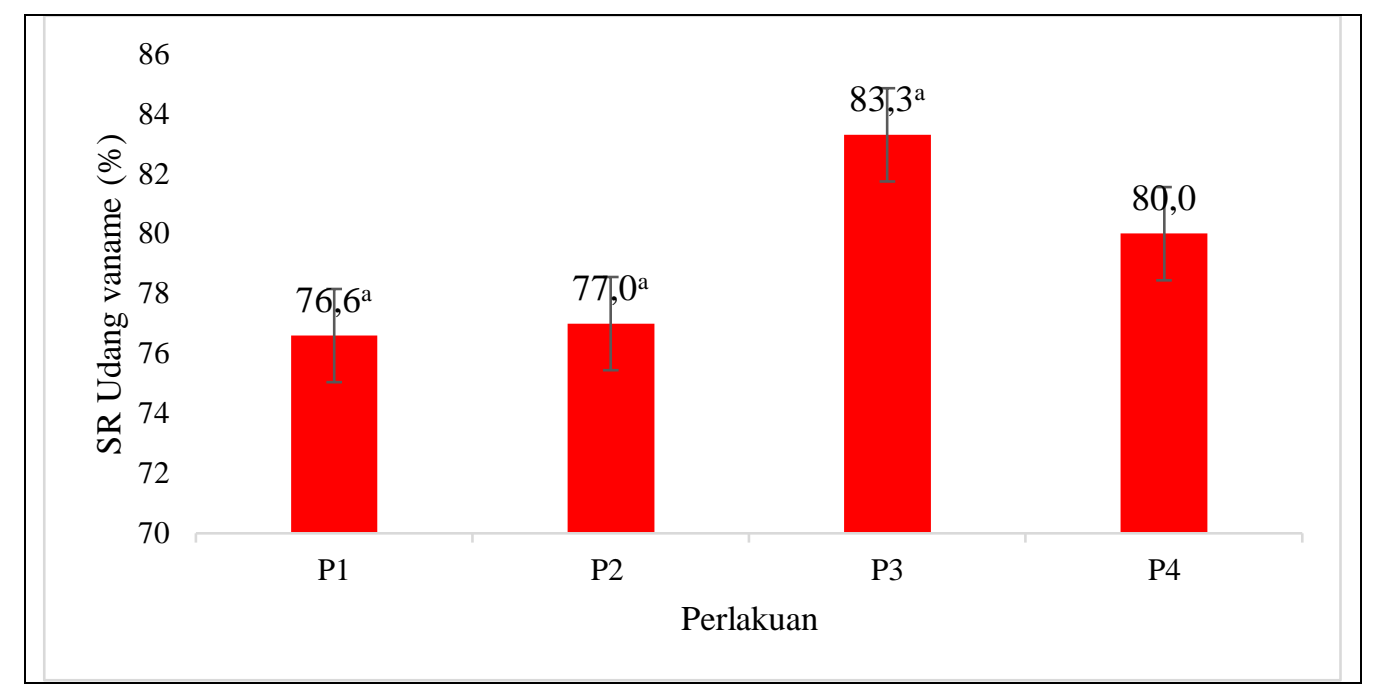

Gambar 5. Grafik Survival Rate (SR) udang vaname setelah pemberian probiotik dengan persentase pakan berbeda selama 45 hari.

Hasil penelitian panjang udang vaname selama 45 hari dilihat dari Gambar 5. memperlihatkan hasil pertumbuhan dari yang terendah sampai yang tertinggi yaitu P176.6\%, P2 77,\%, P4 80\% dan P3 83,3\%. P3 dengan persentase Survival Rate (SR) $83,3 \%$ cendrung lebih tinggi dibandingkan yang lainnya. Perbedaan Survival Rate (SR) udang vaname ini walaupun tidak signifikan disetiap perlakuan diduga karena adanya peran penambahan bakteri Lactobacillus sp., hasil Survival Rate tersebut di atas baik karena penambahan bakteri Lactobacillus dengan persentase pakan berbeda dapat meningkatkan respon imun sehingga, menggeser bakteri negatif yang terdapat pada usus menggunakan asam laktat $\left(\mathrm{H}_{2} \mathrm{O}_{2}\right)$ dan beberapa enzim yang dimilikinya sehingga kematian yang diakibatkan oleh penyakit berkurang. Yulinery et al., (2006) menyatakan bahwa Lactobacillus sp. memiliki kemampuan memproduksi asam laktat menggunakan enzim laktase untuk mengeliminasi bakteri jahat yang bersifat negatif bagi udang vaname atau kompetitornya pada usus.

Hasil uji Survival Rate (SR) udang vaname menggunakan uji KurskalWillace dengan menggunakan faktor koreksi 0,05 menunjukan hasil yang tidak signifikan dengan nilai signifikan 0,571 walaupun ada perbedaan secara angka. Dari hasil penelitian menunjukan bahwa SR udang tertinggi yang diperoleh yaitu $76,7 \%-83 \%$ menunjukan SR yang cukup baik jika dibandingkan dengan SR yang diperoleh dalam penelitian Purnamasari (2017) dengan hasi SR yang diperoleh yaitu 74,3\%-86,7\%. Penelitian Nadhef (2016) dengan hasil SR yang diperoleh yaitu 50\%$67 \%$. Penyebap tingginya SR yang didapat dalam penelitian ini karena penambahan probiotik dengan persentase pakan berbeda mengurangi kematian akibat serangan penyakit yang bermula dari usus. Namun dengan penambahan proboitik dapat menyebabkan respon inmun udang meningkat dan selain itu keadaan bakteri Vibrio dan bakteri agen penyakit lainnya akan tereliminasi oleh keberadaan bakteri Lactobacillus sp. yang masuk ke usus melalui penambahan probiotik pada pakan. Herdianti et al., (2015) menyatakan bahwa penambahan Lactobacillus sebagai probiotik dapat mereduksi keberadaan Vibrio sp. Hal ini dapat memberikan keuntungan bagi pembudidaya udang vaname dan asam laktat yang diproleh dalam proses fermentasi karbohidrat oleh 
Lactobacillus sp. akan menjadi penghambat pertumbuhan bakteri yang bersifat patogen.

Kanibalisme juga mempengaruhi kelangsungan hidup udang vaname. Udang yang sedang mengalami molting biasanya selalu menjadi mangsa bagi udang yang tidak sedang molting. Disaat yang bersamaan antara pakan habis dan udang mengalami molting maka udang yang tidak molting akan muncul sifat kanibalimenya sehingga ada beberapa udang yang ditemukan mati akibat dimakan temannya, sehingga bisa diduga bahwa tingginya kelangsungan hidup udang tidak dipengaruhi oleh tingkat kanibalisme dalam kegiatan penelitian ini. Cara yang dilakukan untuk meminimalisir kematian akibat kanibalisme ini, pada penelitian ini dilakukan pemberia pakan dalam frekuensi yang banyak yaitu 4 kali dalam sehari sehingga kematian akibat kanibalisme bisa teratasi dengan adanya ketersediaan pakan walaupun tidak bisa dipungkiri bahwa sifat kanibalisme udang tetap muncul akibat ketidak tersediaan pakan dalam rentan waktu yang cukup lama di malam hari. Purnamasari et al., (2017), menyatakan bahwa tidak tersedia atau kurangnya ketersediaan pakan dapat memicu kanibalisme udang sehingga terjadinya saling memakan sesama yang kemudian menyebabkan kematian pada udang vaname.

\section{Feed Convertion Ratio (FCR)}

Data rata-rata Feed Convetion Ratio (FCR) didapat dari perbandingan antara jumlah pakan yang dimakan udang vaname Litopenaeus vannamei dengan pertambahan bobot berat udang selama pemeliharaan (45 hari) pada setiap perlakuan. Hasil perhitungan nilai konversi pakan atau Feed Convetion Ratio (FCR), disajikan dalam bentuk grafik pada Gambar 6.

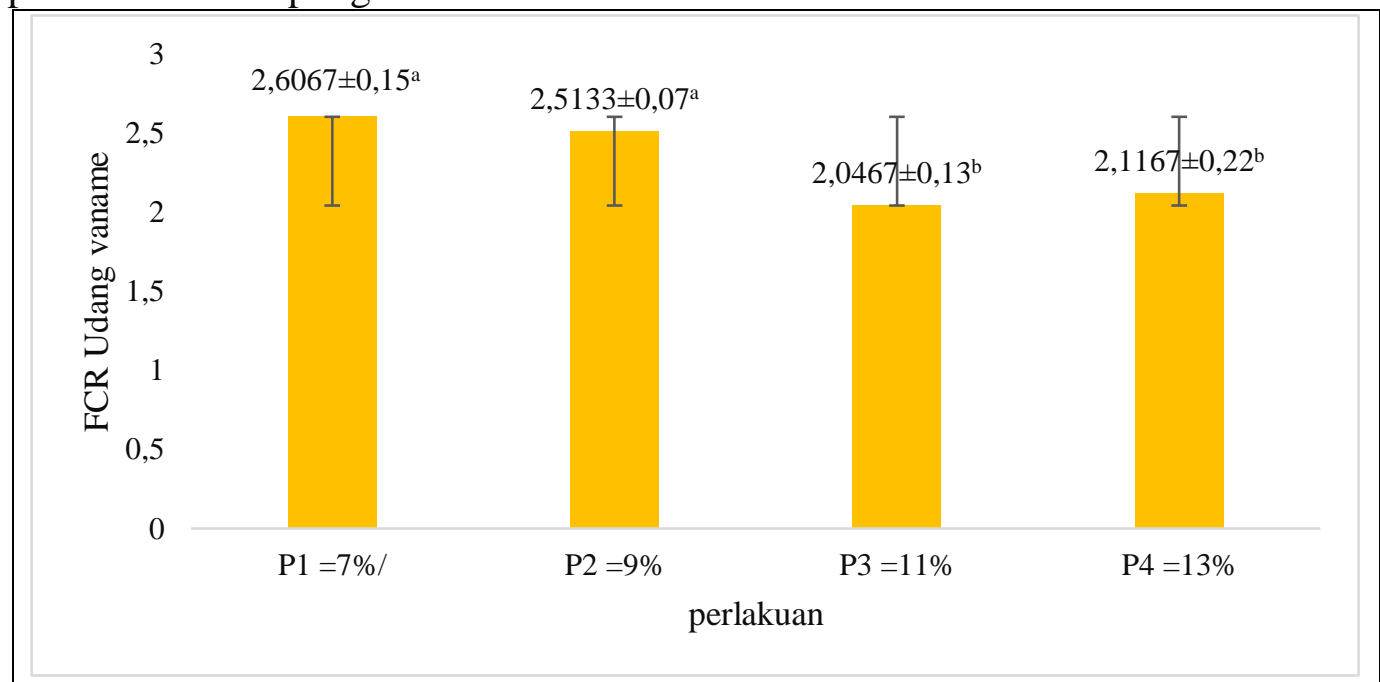

Gambar 6. Grafik Feed Convertion Ratio (FCR) udang vaname setelah pemberian probiotik dengan persentase pakan berbeda selama 45 hari.

Hasil rata-rata Feed Convertion Ratio (FCR) pada grafik diatas mulai dari yang terkecil sampai yang tertinggi yaitu P3 $2,0467 \pm 0,13, \quad \mathrm{P} 4 \quad 2,1167 \pm 0,22$, $\mathrm{P} 22,5133 \pm 0,07 \quad$ dan $\mathrm{P} 12,6067 \pm 0,15$. Perlakuan P3 memiliki nilai Feed Convertion Ratio (FCR) 2,0467 $\pm 0,13$ terendah, artinya memiliki kemampuan yang lebih tinggi mengkonversi pakan menjadi bentuk daging dibandingkan perlakuan lainnya. Hasil ini menunjukkan adanya pengaruh pemberian probiotik dengan persentase pakan berbeda dapat meningkatkan kecernaan makanan. Semakin tinggi kecenaan pakan maka pakan semakin baik. Ini sesuai dengan pernyataan Fernado (2016), Penambahan bakteri Lactobacillus sp. dapat meningkatkan kecernaan pakan akibat penyedehanaan protein kompleks menjadi 
protein yang lebih sederhana sehingga pakan mudah diserap oleh udang vaname.

Hasil uji anova menunjukan bahwa penambahan bakteri Lactobacillus sp. dengan persentase pakan berbeda memberikan pengaruh yang signifikan ( $<<0,05)$ terhadap nilai Feed Convertion Ratio (FCR) udang vaname, sehingga dilakukan uji lanjut menggunakan Tukey dan didapatkan hasil terbaik yaitu pada perlakuan P3 dengan nilai Feed Convertion

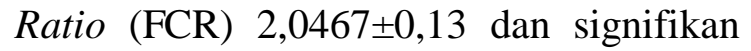
dengan P1 dan P2, namun tidak signifikan dengan P4. Semakin tinggi persentase probiotik yang diberikan semakin memperkecil nilai Feed Convertion Ratio (FCR). Ini dikarenakan pemberian bakteri Lactobacillus sp. dapat menambah populasi bakteri positif pada usus, yang membuat usus menjadi sehat dan optimal dalam menyerap nutrisi pakan yang diberikan. Andriani (2017) menyatakan bahwa penambahan Lactobacillus sp., pada pakan akan menyehatkan usus dan dapat menyederhanakan senyawa-senyawa protein sehingga dalam proses penyerapan makanan menjadi lebih optimal sehingga pakan yang diberikan terfokus pada petumbuhan. Nilai FCR sangat dipengaruhi oleh tingkat kecernaan makanan. Purnamasari et al., (2017), menyatakan behwa semakin tinggi tingkat kecernaan pakan maka semakin baik pakan tersebut untuk pertumbuhan udang. Salah satu cara meningkatkan kecernaan pakan yaitu dengan menambahkan probiotik Lactobacillus sp. pada pakan.

\section{Kualitas Air}

Kualitas air merupakan salah satu faktor yang mutlak diperhatikan secara khusus. Kualitas air yang buruk dapat mengakibatkan udang yang dibudidayakan mati. Kualitas air yang dimonitoring pada penelitian ini diantaranya yaitu kualitas fisika seperti suhu, dan kecerahan, kualitas kimia seperti $\mathrm{pH}$, salinitas, alkalinitas, nitrit, nitrat, amonia dan posfat, magnesium dan kalcium.

Adapun hasil pengukuran kualitas air yang didukung oleh kajian literature dapat dilihat pada Tabel 1.

Tabel 1. Parameter kualitas air penelitian

\begin{tabular}{llll}
\hline Vareabel & $\begin{array}{l}\text { Kisaran } \\
\text { pengukuran }\end{array}$ & $\begin{array}{l}\text { Kisaran } \\
\text { optimal }\end{array}$ & Sumber \\
\hline $\begin{array}{l}\text { DO (Dissoved } \\
\text { Oxygen) }\end{array}$ & $5-7,6 \mathrm{ppm}$ & DO <4 ppm, & $\begin{array}{l}\text { Arsad et al., (2010) dan } \\
\text { Tehe } \text { et al., (2011) }\end{array}$ \\
Suhu & $25,4-$ & $28-30{ }^{\circ} \mathrm{C}$ & $\begin{array}{l}\text { Herdianti et al., (2015) } \\
\text { Tehe } \text { et al., (2011) }\end{array}$ \\
pH & $28,2^{\circ} \mathrm{C}$ & $7,0-8,5$ & $\begin{array}{l}\text { Arsad et al., (2010) dan } \\
\text { Tehe et al.,(2011) }\end{array}$ \\
Salinitas & $7,02-8,21$ & $0,5-49 \mathrm{ppm}$ & $\begin{array}{l}\text { Amri dan Kanna, (2008) } \\
\text { Astuti } \text { et al., (2007) }\end{array}$ \\
& $38-40 \mathrm{ppm}$ & &
\end{tabular}

Nilai parameter kualitas air selama pemeliharaan menunjukkan kisaran yang masih normal dan sesuai dengan kebutuhan udang vaname untuk melangsungkan pertumbuhan dan kelangsungan hidupnya. Nilai kisaran oksigen terlarut (DO) pada kegiatan penelitian ini berkisar antara 5-7,6 ppm. Kisaran nilai oksigen terlarut (DO) ini masih dalam keadaan optimum untuk pertumbuhan dan kelangsungan hidup udang vaname. Menurut Arsad et al., (2010) dan Tehe et al., (2011), oksigen terlarut $>4 \mathrm{mg} / \mathrm{l}$, memberikan pertumbuhan yang cepat dan ketersediaan oksigen 
terlarut (DO) yang baik bagi peliharaan udang vaname dan jika kebutuhan oksigen di dalam perairan tidak tercukupi akan menyebabkan udang vanamestress dan tingkat kelulusa hidup udang akan menurun.

Nilai kisaran suhu pada semua perlakuan berkisar antara $25,4{ }^{\circ} \mathrm{C}-28,2{ }^{\circ} \mathrm{C}$. Herdianti et al., (2015) Tehe et al., (2011), menyatakan bahwa kisaran suhu yang diperlukan untuk budidaya udang yang baik berkisarantara $28-30{ }^{\circ} \mathrm{C}$, karena pada suhu tersebut merupakansuhu yang baik untuk proses metabolisme dan pencernaan makanan dengan baik, sehingga diikuti pertumbuhan dan kelangsungan hidup yang baik pula serta suhu air juga dapat mempengaruhi kelarutan oksigen di dalam perairan dan berpengaruh terhadap proses kimia dan biologi perairan.

Kisaran hasil pengukuran $\mathrm{pH}$ pada penelitian ini, berkisar antara 7,2 - 8,21. keadaan ini masih cukup normal untuk menunjukkan angka yang normal untuk kegiatan budidaya udang vaname di tambak. Arsad et al., (2010) dan Tehe et al., (2011) menyatakan kisaran nilai pH yang baik untuk pertumbuhan dan kelangsungan hidup udang vaname berkisar antara 7,0 8,5 . Nilai $\mathrm{pH}$ yang terlalu rendah (asam) akan membuat udang vaname menjadi lembek akibat penyerapan kalsium tidak dapat berlangsung dengan baik, sedangkan pada kondisi nilai $\mathrm{pH}$ tinggi (basa) akan membut peningkatan amoniak yang bersifat racun bagi udang vaname.

Nilai salinitas pada penelitian ini berkisar antara 23-24 ppm, kisaran salinitas tersebut masih dalam kisaran optimal dalam kegiatan budidaya udang vaname. Menurt Arsad et al., (2010) dan Tehe et al., (2011)bahwa udang vaname dapat hidup dengan baik pada salinitas 0,5-49 ppm, namun salinitas yang palin optimal untuk pertumbuhan udang vaname berkisar antara 15 -25 ppm. Perubahan salinitas yang terlalu tinggi dapat mengakibatkan rusaknya pankreas pada benur yang udang yang masih kecil, selain itu salinitas sangat erat hubungannya denga ketersediaan kalsium.

\section{KESIMPULAN}

Pemberian probiotik dengan konserasi berbeda selama 45 hari memberikan hasil yang berbeda terhadap pertumbahan berat, panjang, Survival Rate (SR) dan Feed Convertion Ratio (FCR) udang vanamei (Litopenaeus vannamei).

1. Pemberian probiotik dengan konsentrasi berbeda menghasilkan berat mutlak tertinggi terdapat pada perlakuan $\mathrm{P}_{4}$ dengan pertambahan berat rata-rata seberat $7,6 \pm 0,23$ gr/ekor namun tidak signifikan dengan perlakuan $\mathrm{P}_{3}$ dengan pertambahan berata rata-rata seberat 7,5267 $\pm 0,07 \mathrm{gr} /$ ekor.

2. Panjang mutlak tertinggi terdapat pada perlakuan $\mathrm{P}_{4}$ dengan pertambahan panjang rata-rata sepanjang $\quad 5,4067 \pm 0,12 \mathrm{~cm} / \mathrm{ekor}$ namun tidak signifikan dengan $\mathrm{P}_{3}$ dengan pertambahan panjang ratarata sepanjang $5,3267 \pm 0,15 \mathrm{~cm} /$ ekor dan $\mathrm{P}_{2}$ dengan pertambahan ratarata panjang sepanjang $4,8633 \pm 0,05 \mathrm{~cm} /$ ekor.

3. Nilai Survival Rate (SR) tertinggi dengan penambahan probiotik berbeda terdapat pada $\mathrm{P}_{3}$ denga persentase Survival Rate (SR) senilai $83 \%$ dan tidak signifikan terhadap semua perlakuan.

4. Nilai Feed Covertion Ratio(FCR)tertinggi dengan penambahan probiotik berbeda terdapat pada perlakuan $\mathrm{P}_{3}$ dengan nilai FCR senilai

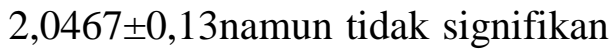
dengan $\mathrm{P}_{4}$ dengan nilai FCR senilai $2,1167 \pm 0,22$.

\section{DAFTAR PUSTAKA}

Amri. K., dan Kanna. I. 2008. Budidaya Udang Vannamei Secara Intensif, Semi Intensif dan Tradisiaonal. Gramedia. Jakarta. 
Andriani Y, Aufa AK, Mia M R dan Ratu S. 2017. Karekterisasi Bacillus dan Lactobacillus yang Dienkapsulasi dalam Berbagai Bahan Pembawa untuk Probiotik Udang Vannamei (Litopanaeus vannamei). Jurnal Perikanan dan Kelautan. Volume:7(2). ISSN 2089-3469.

Arsad S, Ahmad A, Atika PP, Betrina MV Dhira KS, Nanik RB. 2017. Study Of Vaname Shrimp Culture (Litopenaeus Vannamei) In Different Rearing System. Jurnal Ilmiah Perikanan dan Kelautan (ISSN: 2085-5842).

Badan Pusat Statistik (BPS) RI. 2012. Statistik Ekspor Hasil Perikanan Menurut Komoditi, Provinsi dan Pelabuhan Asal Ekspor. Pusat Data, Statistik dan Informasi. 1-1329.

Effendi. M. I.1979. Metode Biologi Perikanan. Bogor. Penerbit Yayasan Dewi Siri

Fernando, E. 2016. Pengaruh Variasi Dosis dan Frekuensi Pemberian Probioti pada Pakan Terhadap Pertumbuhan Serta Motrtalitas Udang Vaname (Litopanaeus vannamei). Program Sarjana, Universitas Airlangga.

Herdianti. L., Kadarwan. S., Sigit. S. 2015. Effectiveness on the use of bacteri improvement white shrimp (Litopenaeus vannamei) super intensiveculture media. Jirnal pertanian idonesia (JIPI). Vol 20 (3): 265-271.

Hidayat. S. S. Suwardi. T dan Agus. N. 2011. Pemasyarakatan Teknologi Budidaya Udang Vannamei (Litopenaeusvannamei) Sistem Polikultur dengan Ikan Bandang (Chanoschanos) Di Tambak Salinitas Rendah. Balai Riset Budidaya Air Payau Maros, Sulswesi Selatan.
Kementrian Kelautan dan Perikanan (KKP). 2018. Produktivitas Perikanan Indonesia pada Forum Mardeka Barat 9 Kementrian Komunikasi dan Informatika. Jakarta

Nadhif Muhamma.2016. Pengaruhan pemberian probiotik pada pakan dalam berbagai kosentrasi terhadap pertumbuhan dan mortalitas udang vannamei (Litopenaeusvannamei). Program Sarjana, Universitas Airlangga.

Novita, D. D. A. 2016. Produksi Pemekatan dan Karakterisasi Enzim Protease Dari Lactobacillus plantarum SK (5). Program Sarjana, Institut Pertanian Bogor. Hal 1-19.

Nuhman. 2008. Pengaruh Prosentase Pemberian Pakan Terhadap Kelangsungan Hidup dan Laju Pertumbuhan Udang Vannamei (Litopanaeus vannamei).Jurnal Berkala Ilmiah Perikanan. Volume: 3(1).

Purnamasari Indah., Dewi. P dan Maya. A. F. U. 2017. Pertumbuhan Udang Vaname (Litopaaeus vanamei) Di Tambak Intensif. Jurnal Enggano Vol: 2(1). ISSN: 2527-5186.

Suwoyo. H. S dan Mangampa. M. 2010. Aplikasi Probiotik Dengan Konsentrasi Berbeda Pada Pemeliharaan Udang Vaname (Litopanaeus vannmaei). Jurnal Balai Riset Perikanan Budidaya Air Payau, Sulawesi Selatan 239-247.

Yulinery, T., Yulianto, E dan Nurhidayat, N. 2006. Uji Fisiologi Probiotik Laktobacillus Sp. Mar 8 Yang Telah Dienkapsulasi Dengan Menggunakan Spray Dryer Untuk Menurunkan Koleterol. Jurnal Biodiversitas. Vol. (7) 2. 118-122. 